\title{
Property Rights Protection and Corporate R\&D: Evidence from China
}

\author{
Chen Lin ${ }^{\mathrm{a}}$ Ping Lin ${ }^{\mathrm{a}}$, and Frank Song ${ }^{\mathrm{b} *}$ \\ ${ }^{a}$ Department of Economics, Lingnan University of Hong Kong \\ ${ }^{\mathrm{b}}$ School of Economics and Finance, The University of Hong Kong
}

November 12,, 2008

\begin{abstract}
In this paper, we examine the effects of property rights protection on corporate innovative activities. Using a unique 2003 World Bank survey of over 2400 firms in 18 Chinese cities, we obtain the following findings: (1) property rights protection is positively and significantly related to corporate innovative activity (for both process and product R\&D); (2) government services and helping hand are conducive to corporate $\mathrm{R} \& \mathrm{D}$, while informal payments to government officials are not; and (3) government ownership of firms and direct appointment of CEOs are important determinants of corporate R\&D. We also find that corporate R\&D is positively related to firm size, and access to finance, but negatively related to product market competition and firm age. We provide a theoretical framework and some policy implications of the findings.
\end{abstract}

Keywords: Property Rights Protection; Government Grabbing Hand; Corporate R\&D JEL code: O3, O12, P20

\footnotetext{
*LIN, Chen: Department of Economics, Lingnan University of Hong Kong, chen.lin@ln.edu.hk; Tel.: (852)2616 7200; Fax: (852)2891 7940. LIN, Ping (Corresponding author): Department of Economics, Lingnan University of Hong Kong and Shandong University, China plin@ln.edu.hk; Tel.: (852)2616 7203; Fax: (852) 2891 7940. Frank Song: School of Economics and Finance, The University of Hong Kong, fmsong@econ.hku.hk; Tel.: (852) 2857 8507; Fax: (852)2548 1152. The authors would like to thank Belton Fleisher, Sarah Tong and Colin L. Xu, and participants at Chinese Economists Society (CES) Annual Meetings (2007) in Changsha, China for useful comments and suggestions.
} 


\section{Property Rights Protection and Corporate R\&D: Evidence from China}

\section{Introduction}

The most important question in the field of economic growth and development is: Why are some countries much poorer than others? Traditional neoclassical theory, following Solow (1956), explain differences in income per capita in terms of different saving rates or some exogenous factors such as total factor productivity. Recent theory of economic growth, following Romer (1986, 1990) and Lucas (1988), endogenizes steady-state growth and technical progress. According to the model of Romer (1990), e.g., a country may be more prosperous than another if it allocates more resources to $\mathrm{R} \& \mathrm{D}$.

Most recently, a new approach to studying economic growth and development has emerged which emphasizes the role of economic institutions (e.g. Acemoglu et al., 2002, 2005; Barro 1990; Beck et al., 2005; Claessens and Laeven, 2003; Djankov et al., 2003; Johnson et al., 2002; La Porta et al., 1998, 2002). This new approach takes the view that the classical theories of economic growth, while providing many insights about the mechanics of economic growth, seem unable to provide a fundamental explanation for economic growth and development (Acemoglu, 2005). As North and Thomas (1973, p.2) put it, "the factors we have listed (innovation, economies of scale, education, capital accumulation etc.) are not causes of growth; they are growth" (italics in original). According to the aforementioned new studies, the fundamental explanation of comparative growth is differences in institutions.

Of particular importance to economic outcomes are the economic institutions such as the protection of property rights and the presence and perfection of market ${ }^{1}$. Property rights are important because they influence one’s incentive to invest in tangible or intangible capital or adopt more advanced technology (Claessens and Laeven, 2003). In his influential book, North (1990) views property and contract rights as key to channeling resources toward productive

\footnotetext{
${ }^{1}$ As Levine (p. 61, 2005) points out, "the security of property rights . . . is not a natural occurrence; rather it is an outcome of policy choices and social institutions.”
} 
investments: "The inability of societies to develop effective, low-cost enforcement of contracts is the most important source of both historical stagnation and contemporary underdevelopment in the Third World.” Recent studies show that strong property rights protection and contract enforcement enhance corporate governance, firm valuation, investments in physical and financial assets, asset allocation and thereby economic growth (e.g. Barro, 1990; Claessens and Laeven, 2003; Cull and Xu, 2005; Demirguc-Kunt and Maksimovic, 1998; Johnson et al. 2002; Knack and Keefer, 1995; King and Levine, 1993; Mauro, 1995). ${ }^{2}$

This literature, however, has not yet touched on the effects of structure and protection of property rights on firm incentives to conduct $R \& D$ which aims at producing new products and new technologies, which are essential for long-run and sustainable economic growth. Our paper tries to fill this void in the literature.

Following the recent literature (e.g., Johnson et al., 2002; Cull and $\mathrm{Xu}, 2005$; Levine, 2005) on property rights and finance, we measure property rights security at various dimensions and examine the effects of property rights protection on corporate R\&D. Levine (2005) summarizes the security of property rights into two important dimensions: (1) an active government that enforces property rights, facilitates private contracting, and applies the law and rule fairly to everyone; and (2) a government that sufficiently constraints itself from coercion and informal payments. Using a unique set of World Bank survey data of Chinese firms in 18 cities in 2003, these two dimensions can be measured by a series of variables that are constructed based on firms' perceptions about property rights protection, contract enforcement and government grabbing hand/helping hand. ${ }^{3}$ Moreover, following Cull and Xu (2005) we measure

\footnotetext{
${ }^{2}$ For example, Barro's (1990) classic empirical study on the effects of political instability, which he interpreted as "adverse influences on property rights", found that frequencies of revolutions, coups, and political assassinations are negatively related to the growth rate and to private investment. Using broader measures of the quality of governance, including measures of corruption, bureaucratic quality, rule of law, informal payments risk, Mauro (1995), Knack and Keefer (1995), and Keefer and Knack (1997) found further evidence that improved quality of governance promotes economic growth. King and Levine (1993) and Demirguc-Kunt and Maksimovic (1998), among others, present similar evidence with regard to investment in financial assets. Johnson et al. (2002) and Cull and Xu (2005) find that property rights protection is positively associated with firm's profit reinvestment rate.

${ }^{3}$ The 18 cities range from developed coastal cities such as Shenzhen and Hangzhou to relatively backward cities such as Lanzhou and Guiyang, providing a rich sample of cities at different levels of property rights protection and government efficiency. Similar measures have been used in Johnson et al. (2002) and Cull and Xu (2005).
} 
the security of property rights at the firm level as different types of corporate ownership and control. As Jefferson and Rawski (2002) and Cull and Xu (2005) point out, state ownership is often associated with vaguely defined property rights, a higher level of informal payments risk, greater chance of political intervention, and the pursuit of non-economic objectives at the expense of other shareholders and thus implies a low level of property rights security. We obtain the following empirical results. First, measures of property rights protection—for instance, the likelihood that the legal system will uphold contracts and property rights—-have a positive and significant relationship with corporate $R \& D$ intensity. Second, corporate $R \& D$ investments are positively and significantly related to the extent of the government's helping hand. We also find that compared with state ownership, both private and foreign ownership facilitate corporate R\&D in China. Government appointment of CEOs of stated owned enterprises also has a negative impact on firm R\&D.

Following the approach of North (1990) and the subsequent studies, we view firm R\&D decisions as responses to the "rules of the game in society" that "structure incentives in human exchange”. As basic rules in a market economy, property rights (including IPRs) protection and contract enforcement affect corporate incentives for investments of all kind, both in tangible and intangible assets. While IPRs laws and enforcements provide necessary protection to the fruits of R\&D (patent, copyrights, trademarks, etc.), broader property rights protection and contract enforcements protect investments that are complementary to $R \& D$ expenditures, especially during the post-R\&D stage, and hence help realize the commercial values of $R \& D$. The unique firm-level information in our dataset enables us to examine empirically the effects of property rights protection and contract enforcement on $\mathrm{R} \& \mathrm{D}$

Government services can also have a significant effect on corporate R\&D, especially in developing countries where market mechanisms are generally not perfect and a large range of economic transactions and contract enforcement are affected, either positively or negatively, by 
the "visible hand". On the one hand, by extending a "helping hand" to corporations, government services are conducive to a firm’s economic activities, including R\&D investments. On the other hand, the government sometimes places a "grabbing hand" on business enterprises by, e.g. introducing new policies, imposing regulations that increase the costs of doing business ${ }^{4}$. Sometimes government officials even demand informal payments from firms. ${ }^{5}$ Such a grabbing hand tends to hinder firm incentive to innovate by lowering the returns of R\&D.

Furthermore, state ownership of firm property and government direct control of firms via CEO appointment, which are common in developing countries, can have a big influence over corporate R\&D decisions. First, the government may directly own shares of an enterprise as a means to foster employment or fulfill other social goals, which may in turn impact a firm's R\&D decisions. ${ }^{6}$ Managers of state-owned or state-controlled firms also tend to give higher priority to the demands of bureaucrats than to those of minority stakeholders, simply because of the influence bureaucrats have over their employment contracts. When firms are dominated by bureaucrats who pursue their own private interests, the risk of CEO turnover or demotion is likely to be decoupled from a firm's performance, and instead influenced by how well CEOs serve the private interests of the bureaucrats. Furthermore, SOE managers have weak or sometimes adverse innovative incentives to improve firm competitiveness, since as public employees, they cannot personally reap the benefits of increasing competitiveness, yet they will bear many of the costs of the R\&D (e.g., uncertainty of the investment and angry workers) (Megginson, 2005). For the above reasons, the effects of government ownership and direct

\footnotetext{
${ }^{4}$ As pointed out by Shleifer and Vishny (1993, p.601), "an important reason why many of these permits and regulations exist is probably to give officials the power to deny them and to collect bribes in return for providing the permits”.

${ }^{5}$ Such informal payments are usually ways to bribe government officials. In many cases they are disguised as different types of fees, trip offerings, expense money, home decorating assistance, or gambling activities.

${ }^{6}$ In their survey of corporate governance, Shleifer and Vishny (1997) argue that SOEs are actually controlled by bureaucrats who have extremely concentrated control rights but no significant cash flow rights, since the latter are widely dispersed amongst the country's taxpayers. Bureaucrats' main concerns are to achieve their political objectives and to secure their economic benefits, which are often quite different from the objective of increasing SOEs' competitiveness and maximizing profits (Shleifer and Vishny, 1994). Therefore, state owners are thought to be unwilling to undertake high-risk and long-term $R \& D$ projects because the cost of doing so is much greater than the political/electoral payoff of modestly improving SOE competitiveness and performance (Megginson, 2005).
} 
control on corporate R\&D activities are likely to be negative.

China is suitable for the purpose of our study for the following reasons. First, as the largest developing economy with the fastest economic growth, China lacks a well-developed legal and institutional environment. ${ }^{7}$ It may seem puzzling how China has achieved such an economic miracle in the absence of a well-established legal system. In fact, some have viewed China as a significant counter-example to the existing literature on law, institutions, and growth (Allen, Qian, and Qian, 2005). ${ }^{8}$ Our findings on the role of government in corporate R\&D shed some light on this issue. Second, as the most populated economy in the world, China's development has been unbalanced across its regions. Property rights protection (law enforcement in particular) varies greatly over different parts of China. The 18 cities in our sample range from developed coastal cities to relatively backward cities, providing a rich sample of cities at different levels of property rights protection.

There have been extensive studies of the effects of intellectual property rights (IPRs) protection on R\&D in developing countries during the past two decades, often in a North-South framework (see, e.g., Grossman and Helpman, 1991; Helpman, 1993; Glass and Saggi, 2002; Branstetter, Fisman and Foley 2006) . The recent work of Chen and Puttitanum (2005) derived in their theoretical model and then confirmed with international data that a developing country's optimal level of IPRs, one best trading off encouraging domestic firms' imitation of foreign technology and promoting domestic R\&D, can exhibit a U-shaped relationship with its levels of economic development. This literature on R\&D and economic development, however, has focused mostly on protection of IPRs, and not paid much attention to broad property rights protection, which is the focus of our paper.

Our findings complement the recent work of Chen and Puttitanum (2005) by providing evidence that broad property rights (including IPR) protection promote R\&D investments. Our

\footnotetext{
${ }^{7}$ China passed its Property Law in March 2007, after considerable controversy during the past decade. La Porta, Lopez de Silanes, Pop-Eleches, and Shleifer (2004) ranked China among the worst countries in terms of political freedom as well as property rights protection

${ }^{8}$ As Allen, Qian, and Qian (2005) point out, the success of the private sector in China challenges the traditional view that property rights and a lack of government control are necessary for economic growth.
} 
study also adds to the recent studies on firm R\&D in China (e.g., Hu and Jefferson, 2004; Hu, Jefferson, and Qian, 2005) that examine the impact of R\&D and technology transfer on firm productivity. By focusing on the role of property rights and government in corporate $R \& D$ decisions, we explore the institutional factors that affect technological progress in China. Our findings provide a clear message to policy makers in developing countries: sound property rights protection, a just legal system, and a clean government with a "helping hand" instead of a "grabbing hand" are crucial to encouraging corporate $R \& D$ and long-term economic development. This finding echoes the recent study by Li and Zhou (2005) who find that government officials have a political incentive to promote local economic growth.

Nevertheless, some caveats still exist. While we document that stronger property rights protection are associated with more corporate $R \& D$ and innovations, we are not claiming that we have ruled out all the possibilities of potential endogeneity though we have done some instrumental variable analysis in the paper. Instead, we hold that we at least present evidence of interesting correlations between property rights protection and corporate $\mathrm{R} \& \mathrm{D}$, which are robust to IV analysis with reasonably exogenous instruments.

The rest of the paper is organized as follows. Section 2 develops a theoretical framework to analyze the role of property rights protection and the government in corporate R\&D activities. Section 3 discusses the World Bank survey data and presents the data and variables used in the empirical analysis. Section 4 presents the empirical results. Section 5 concludes.

\section{A Theoretical Framework}

As mentioned in the Introduction, our analysis goes beyond the standard arguments of legal protection of intellectual property rights; we examine the effects of broad property rights protection on corporate $R \& D$. We view $R \& D$ investments as responses to the basic "rules of the game” in society which define property rights protections, the most fundamental element of economic institutions. 
$\mathrm{R} \& \mathrm{D}$ is a process via which firms generate new products and new processes which can be commercialized afterwards (either by the firms themselves or by licensing the R\&D to other parties). Property rights protection impacts on a firm's incentive for $R \& D$ by influencing the economic and legal factors during both the R\&D stage and the commercialization stage. During the $R \& D$ stage, a firm decides on the intensity and scope of its $R \& D$ investments and chooses the mode of R\&D (e.g., via collaborations with outsiders). The firm also needs to find ways to protect the interim and final fruits of its $R \& D$ effort, either by obtaining patent protection or keeping them as trade secrets. Better property right protection (particularly intellectual property right protection) and a well established legal system can help guard the knowledge generated by a firm’s R\&D process and prevent its illegal possession and usage by other parties. Government can also play a direct role in the $\mathrm{R} \& \mathrm{D}$ stage by, e.g., providing $\mathrm{R} \& \mathrm{D}$ subsidies/sponsorship, facilitating or coordinating $R \& D$ collaborations among firms, their suppliers/customers, and universities and government research institutes, etc.

Post R\&D, firms need to build production lines and facilities in order to realize the commercial value of their R\&D investments. The returns to the combined R\&D investment and post-R\&D physical investments depend crucially on the degree of property rights protection and government's helping hand. In an economy where property rights protection is weak, and thus firms’ physical assets as well as products are not well protected, one’s incentive to invest in these assets will be hindered. ${ }^{9}$ This negative incentive on post-R\&D investment feeds back to the $R \& D$ stage and lowers the return of $R \& D$. An effective legal system to protect property rights and enforce contracts will facilitate business operations and hence help promote $R \& D$ investment. Similarly, government helping (grabbing) hand in business operations in the postR\&D stage also tend to raise (lower) the return on R\&D investment and hence promote (hinder) innovative activity by firms.

\footnotetext{
${ }^{9}$ This argument for the effect of property rights protection (for tangible as well as intangible property) is broader than the standard argument that intellectual property rights protection promotes R\&D.
} 
Besides protecting property rights and granting a helping hand (or imposing a grabbing hand) over business firms, government direct ownership and control also significantly affect corporate decisions, including that of R\&D. According to the social theory of state ownership of Atkinson and Stiglitz (1980), state-owned enterprises are created to overcome certain market failures when the social benefits of firm actions exceed the costs. One major and commonly recognized social responsibility (SR) of SOEs is to maintain a certain employment level in the economy by providing job opportunities (often beyond the profit-maximizing level; see Shleifer, 1994). The social responsibilities of SOEs may also include offering high-quality products and services to consumers, protecting the environment, pursuing R\&D to become the industry champion and/or to catch up with competitors from advanced countries, and so forth. The degree to which a firm fulfills its social responsibilities depends on, among other things, its R\&D investments in developing cost-reducing processes or new products.

R\&D investment impacts a firm’s social responsibilities, since it affects the number of workers the firm will employ during and after the R\&D process. For instance, the firm may decide to cut labor costs after it develops certain new production processes. Similarly, a new product developed and introduced by the firm may imply the need to close down some of its existing product lines, leading to reallocation of labor forces within the firm. (Frank, Do we have some anecdotal evidence on this from Chuntao for the JCE paper? Still waiting for Chuntao's reply). In cases like this, $\mathrm{R} \& \mathrm{D}$ investment may go against the firm’s social goal of maintaining employment if it leads to layoffs as a result of cost-reducing R\&Ds. However, SOEs may shoulder other social responsibilities that may encourage them to conduct R\&D. For instance, some SOEs may be expected to grow larger and stronger so as to become and maintain the national champions and catch up with international competitors. Or, SOEs may need to come up with new production processes or new products that are more environmental friendly, in a pace faster than private firms. Therefore, a priori state ownership of enterprises may either encourage or discourage corporate $\mathrm{R} \& \mathrm{D}$, due to its distinct social objectives. 
To summarize, strong property rights protection facilitates corporate innovative activities. The helping hand extended by the government also helps corporations innovate. By contrast, the potential informal payments of firm profits by the government (the grabbing hand) are detrimental to corporate incentives to innovate. Finally, whether direct government ownership encourages a firm to innovate depends on the trade-off between the government's goal of maintaining stable employment and other social objectives. In the following sections, we use data from China to examine these implications empirically.

\section{Data and Variables}

\subsection{Sample}

Most data used in the study come from the business environment and enterprise performance survey conducted jointly by the World Bank and the Enterprise Survey Organization of China in early 2003. To achieve a balanced representation of enterprises, the sample includes about 2,400 enterprises from the following 18 cities across five regions in China: (1) the Central Region: Changsha, Nanchang, Wuhan, and Zhengzhou; (2) the Northeast Region: Benxi, Changchun, Dalian, and Harbin; (3) the Northwest Region: Lanzhou and Xi'an; (4) the Southwest Region: Chongqing, Guiyang, Kunming, and Nanning; and (5) the Coastal Area: Hangzhou, Jiangmen, Shenzhen, and Wenzhou. Thirteen of the cities are provincial capitals, while the remaining five are major industrial cities. The survey includes firms with different ownership structures and of different sizes.

The main purpose of the survey is to identify the driving factors behind and obstacles to enterprise performance and growth in China. The first part asks firm managers to answer questions about market structure, vertical relationships with clients and suppliers, relationships with the government, international trade, the institutional environment, access to finance and infrastructure services, corporate governance, the ownership structure of the firm, and information on taxation. The second part asks the firm's accountant and personnel manager to provide information on financial statements, employee training, and wages, etc. While most of 
the qualitative questions in part one pertain to 2002, many of the quantitative variables in part two contain observations from 2000 to 2002. Hence, in the full-sample regression analysis of this paper, some qualitative variables are time invariant, while some quantitative variables vary over the time period. In addition to the firm-level data, we collect the macro control variables from the City Statistical Yearbook of China. Table 1 provides summary statistics of the key variables that we describe below.

[Insert Table 1 here]

\section{2. $R \& D$ investment}

The R\&D measure is the dependent variable in our analysis. We construct two widely used measures of R\&D using data from the survey. The first measure is a dummy variable that equals 1 if the firm made positive investment in $\mathrm{R} \& \mathrm{D}$ in a specific year ( $R \& D$ Dummy), while the second measure is the amount of $\mathrm{R} \& \mathrm{D}$ spending as a percentage of total sales ( $R \& D$ Intensity). Overall, more than $25 \%$ of the enterprises reported making positive R\&D investment during the survey periods (Table 1). As Table 2 shows, the responses vary substantially across cities. For instance, over $50 \%$ of the enterprises in the coastal Hangzhou city report making positive R\&D investment, while less than $10 \%$ of the enterprises in Lanzhou in the west part of China invested in $R \& D . R \& D$ intensity in the surveyed cities (for $R \& D$ active enterprises) ranges from $0.5 \%$ to 2.9\%, which are not low by the Chinese standards.

[Insert Table 2 here]

Cull and $\mathrm{Xu}$ (2005) explore the impact of property rights protection and firm access to finance on profit reinvestment using the same dataset as ours and find significant relationships between property rights protection, access to finance and profit reinvestment. Generally speaking, profit reinvestment could be used to finance R\&D activity. However, we find that the correlation coefficient between R\&D intensity and profit reinvestment rate is a very modest amount, 7.18\%. In fact, Cull and Xu (2005) report that firm owners in the sample reinvest $27 \%$ of their profits on average,whil

e in our study the average ratio of $\mathrm{R} \& \mathrm{D}$ spending to sales is only $0.6 \%$. This discrepancy might 
be due to the fact that profits are much smaller than sales. For instance, based on our sample average ROS (13.88\%), the R\&D intensity would be around $4.2 \%(0.6 \% *(1 / 13.88 \%))$ if it is scaled by profits.

To get a more thorough understanding of the potential relationship between profit reinvestment and $R \& D$ variables in the dataset, we compare their values across firms with various sizes in detail. We find that larger firms are more likely to invest in $R \& D$ and tend to invest more. Nevertheless, the profit reinvestment rate is very similar and stable across firms with different sizes. For instance, for small firms (number of employee $<100$ ), the mean reinvestment rate is $16.11 \% ; 13.6 \%$ of the firms invest in $R \& D$ and the mean $R \& D$ intensity is $0.51 \%$. In contrast, for medium size firms $(100<$ number $<300)$, the mean reinvestment rate is $19.85 \%$; while $29.4 \%$ of the firms invest in R\&D and the mean R\&D intensity is $0.66 \%$. For large firms (number of employee $>300$ ), the mean reinvestment rate is $18.33 \%$; while $45.8 \%$ of the firms invest in $\mathrm{R} \& \mathrm{D}$ and the mean intensity is $6.9 \%$. For brevity, the detailed comparisons are not reported in the tables but are available from the authors.

(Chen, it just occurred to me that we classify firms here as L, M, and S here, whereas later on in Table 8 as two groups (above and below mean). Hope this will not cause referees to ask for consistency. They should understand that these are not crucial. )

The weak correlation between $R \& D$ investment and profit reinvestment found in our sample can be understood as follows. On the one hand, while retained profits can be an important (internal) source of R\&D funding, they are not solely for R\&D purposes obviously: retained earnings can be used for non-R\&D related physical investments (as expansion of their businesses, e.g.) as well. On the other hand, firms may be able to finance their R\&D projects using part of their funds raised by issuing equities and/or attracting venture capitals, or by obtaining external funding from banks or government R\&D promotion programs. Besides the qualitative difference between the R\&D investment and profit reinvestment, their weak correlation also shows that they are not linked quantitatively in any significant pattern, although they are both affected by the degree of property rights protection, as our findings shown next and those documented by 
Cull and $\mathrm{Xu}(2005)$.

\subsection{Legal environment and contract enforcement}

In our study, the empirical analysis includes two variables related to the legal environment and contract enforcement. The first is a dummy variable indicating whether a firm usually signs written contracts with its clients (Contract). Since a firm will sign a contract only if it expects it to have some disciplinary effect in a business dispute, the variable is used as a proxy of a firm's confidence in the contract enforcement system (Cull and $\mathrm{Xu}, 2005)$. The second variable we use (Contract Upheld) is the manager's response to the question: "What is the likelihood that the legal system will uphold my contract and property rights in business disputes?” The responses to the question range from 0 to 1 , with a mean of $64 \%$ and standard deviation of 39\%. As explained in the model, a better legal environment and contract enforcement should enhance a firm’s R\&D incentive.

\subsection{Government helping hand and grabbing hand}

The key independent variables of our study depict the government's role in property rights protection, law and contract enforcement, and direct ownership and control of enterprises. Following the recent literature (e.g., Johnson et al., 2002, and Cull and Xu, 2005), we divide the relevant variables into three groups: (1) variables that measure the extent of the helping and/or grabbing hand of the government; (2) variables that measure the ease and reliability of contract enforcement; and (3) variables that measure government ownership and control of firms. In this section, we focus on the first group of variables. The other two groups will be discussed in the following sections.

The first measure we use is based on the key question in the survey concerning the extent to which the government acts as a helping rather than a grabbing hand (Helping Hand). The question takes the following form: “Among the government officials that your firm regularly 
interacts with, what is the share that is oriented toward helping rather than hindering firms?” The mean of the responses is $34 \%$, with a standard deviation of $31 \% .{ }^{10}$ In Hangzhou and Jiangmen, about $50 \%$ of firms report receiving a helping hand from government officials, while less than $25 \%$ report doing so in many other cities (e.g., Lanzhou, Wenzhou, Nanning, Guiyang, and Dalian). The second variable measuring the government's helping hand (Efficient Service) is based on the manager's response to the survey question: "What is the share of government officials that deliver efficient services (e.g., public utilities, transportation, security, education, and health)?” The mean of the responses to this question is $36 \%$, with a standard deviation of 33\%. In Hangzhou and Chongqing, about 50\% of the firms report receiving efficient services from government officials. The third variable measures the extent to which the government acts as a grabbing hand. The variable is based on the manager's estimate of informal payments to government officials as a percentage of the firm's total sales (Informal payments). The mean response to this question is $0.024 \%$, which indicates a relatively modest effect. Comparing Hangzhou with Lanzhou, the cities with the highest and lowest percentage of firms conducting $R \& D$, respectively, we find some interesting patterns. In Lanzhou, about $23 \%$ and $22 \%$ of the firms report receiving a helping hand and efficient service from government officials, respectively. In contrast, more than $50 \%$ of the firms in Hangzhou report receiving a helping hand and efficient service from government officials. [Ping, can you talk about the Wenzhou here. Inserted right before Table 4 as well as on page 21] The average informal pay in Lanzhou is $0.041 \%$, while the average informal pay in Hangzhou is $0.013 \%$. In a city with most privatized firms, Wenzhou (87.7\% private firms), only $20.6 \%$ and $21.1 \%$ of firms report receiving government help and efficient service, and subsequently only $21 \%$ of companies in Wenzhou engage $R \& D$. This shows that privatized firms are subject to some discriminations from the government. These comparisons provide some crude evidence that the government's helping hand improves a firm's R\&D incentives, while the grabbing hand reduces its R\&D incentive.

As a caveat, we should point out that some of the independent variables discussed above (e.g. Helping Hand, Efficient Service) may be based on subjective judgment or perception of firm managers surveyed, which might result in potential measurement errors. However, as

\footnotetext{
${ }^{10}$ This is similar to the findings reported by Allen, Qian, and Qian (2005). In their survey of 17 Chinese enterprises, $40 \%$ of the survey firms received support from the local government without a demand for profit sharing.
} 
pointed out by BDL (2006), there are good reasons for believing that these self-reported data are not biasing the results in favor of their or our findings (pp. 2136-2137, BDL). Similar to their arguments, if subjective judgment in answering questions such as "contract uphold" and/or "government provide efficient service" represents pure measurement error, it would bias the results against finding a significant relationship between property rights protection measures and firm decisions (R\&D investment in our study, or profit reinvestment in Cull and $\mathrm{Xu}, 2005$ ). Furthermore, additional work done or cited in BDL show that the survey data by the World Bank are indeed associated with measurable outcomes in terms of efficiency of investment flows, firm growth, institutions, corruption and property rights, as shown in several recent and influential studies (e.g., Johnson et al. 2002; Djankov et al., 2003; Beck, Demirguc-Kunt and Maskimovic, 2005; Acemoglu and Johnson, 2005; Cull and Xu, 2005; Ayyagari et al., 2007). Lastly, we conduct instrumental variable analysis as robustness test and find the results very consistent to our main findings. The instrumental variables and relevant results are discussed in detail in section 4.2.

\subsection{Ownership and control}

We use two types of variables to distinguish firm ownership. First, based on their legal status, firms are classified into privately owned domestic firms (Private), wholly foreign-owned enterprises (Foreign Enterprise), joint ventures (Joint Venture) and state-owned enterprises $(S O E)$. Also, to take the advantage of our unique dataset, we use the share of private ownership (Private Ownership) and the share of foreign ownership (Foreign Ownership), both ranging from 0 to $100 \%$, as finer measures of firm ownership. In our analysis, the SOEs are the benchmark group. As Table 3 shows, firm ownership varies substantially across the cities in our sample. The sample mean of private ownership ranges from 25\% in Dalian and reaches $88 \%$ in Wenzhou, arguably the leading Chinese city in terms of the development of private enterprises. The average foreign ownership is high in those cities which are among the first to open to foreign investors such as Dalian and Jiangmen (above 25\%) In contrast, the average foreign ownership is quite 
low (about 1\%) in cities with relatively more traditional heavy industries such as Benxi or some inner land cities such as Guiyang.

Besides direct ownership, another way for the government to influence firm action is to exert control over the management selection process or directly select top managers to represent the state's interests. In our dataset, there is one unique question that asks about the appointment of the CEO. Two dummy variables (State-Appointed CEO and State-Approved CEO Nomination) are created based on the question. State-Appointed CEO equals 1 if the general manager is appointed by the government, and 0 otherwise. State-Approved CEO Nomination equals 1 if the general manager is nominated by the firm and approved by the government agency. In the benchmark group, the CEO is appointed by the board of directors and/or by the shareholders' meeting. From Table 3, we see that CEO nominations need to be approved by the government for about $5 \%$ to $22 \%$ of the firms in the surveyed cities.

\section{[Insert Table 3 here]}

\subsection{Other firm control variables}

In addition to the variables discussed above, our analysis also includes several enterpriselevel controls, such as market competition, firm size, firm profitability, access to finance, and firm age. The so-called Schumpeterian hypothesis claims that $R \& D$ is fostered either by a climate in which firms are large or in industries that have less competition. ${ }^{11}$ Therefore, we use market structure and firm size as two important firm-based control variables. These two variables are used extensively in the literature as important R\&D determinants (e.g. Scherer, 1992; Cohen and Klepper, 1996). A widely used measure of market competition is the number of competitors (Nickell, 1996). In the survey, the relevant question concerns the number of domestic competitors faced by the firm in its main business line or service (Competition). The responses to

\footnotetext{
${ }^{11}$ However, Porter (1990) argues that a positive causal relation exists between competition and growth, since competition forces firms to innovate and be efficient. Grossman and Helpman (1991) show that competition hurts R\&D and economic growth when it facilitates imitation.
} 
the first question are categorical ( 1 - 1 3 competitors, 2 - 4 6 competitors, 3 - 7 15 competitors, 4 - 16 100 competitors, 5 - more than 100 competitors). To proxy the firm size, we use the natural logarithm of total sales (Firm Size). The firm's profitability is measured by the lagged one time period return on sales (Lagged ROS). Firms with higher profitability should have more capability to conduct R\&D. We therefore expect a positive link between profitability and R\&D investment. A firm's access to finance is another variable used as a control variable. We believe that access to bank finance should help ease the financial burden of corporate R\&D. For example, McMillan and Woodruff (2002) and Cull and Xu (2005) argue for the importance of access to external finance to corporate reinvestment. To the extent that $R \& D$ is an important long-term investment, we expect access to finance to be essential to corporate R\&D investment as well. Access to Finance is a dummy variable that equals 1 if the firm has access to bank loans and 0 otherwise. Firm age is the number of years since the firm's establishment (Firm Age). It is believed that as firms age, they tend to look more inward and to have less impact on overall technological R\&D (e.g., Argyres and Silveman, 2004). Therefore, firm age may also be an appropriate control variable in our analysis. Finally, industry control variables are included in the analysis to control for possible heterogeneity arising from industry characteristics.

The correlation coefficients among firm level variables are presented in table 4. As can be seen from the table, multicollinearity is not a serious problem of the firm-level variables. Most of the correlation coefficients are below 0.4, which makes us comfortable to include these variables in the models simultaneously. Furthermore, we can see that government Helping Hand and Efficient Service are positively associated with R\&D investment decision. Contract and Contract Upheld are positively correlated with R\&D as well. SOE and state controlled firms are negatively correlated with the R\&D investment decision. This provides us some preliminary evidence about the impact of property rights and government on R\&D investment.

Among the independent variables, an interesting pattern is worth mentioning. As table 4 shows, the correlation between Contract and Private Ownership is the opposite of its correlation with State Ownership. Similarly for Contract Upheld. In particular, Private Ownership is 
positively correlated with Contract but negatively correlated with Contract Upheld. ${ }^{12}$ These suggest that firms with greater shares of private ownership tend to rely more on contracts in conducting their business but have a less confidence in the Chinese courts in dealing with contractual disputes and protecting their property rights. In contrast, State owned companies have greater confidence in the court, although they rely on less frequently written contracts with their clients, which is plausible given that SOEs have traditionally replied on administrative channels in maintaining their supplier-clients relationship ${ }^{13}$.

One way to understand the negative correlation between private ownership and confidence in the court system in China is as follows. During its current stage of economic development, China's judicial system is far from independent. In fact, SOEs are more likely to prevail in court disputes, relative to privately owned firms. Similarly, FIEs may also be treated more generously by courts in China in business disputes, possibly because of that attracting FDI has been a top priority of local governments which often can influence decisions of local courts.(e.g., Huang (2003) argues that China’s huge FDI may partly due to favorite treatments such as tax subsidies and access to loans received by foreign invested enterprises (FIEs)).

[Insert Table 4 here]

Our empirical analysis also includes city and industry fixed effects to control for the potential differences in economic development and institutions across regions and the technological differences across industries ${ }^{14}$.

\section{Empirical Results}

\footnotetext{
${ }^{12}$ For example, Wenzhou is the city where development of private ownership and innovation is among the most successful in China, and yet it registers the lowest in terms of Contract Upheld among the 18 cities in our sample.

${ }^{13}$ In the data, SOEs have shown greater confidence on government's ability to uphold contract than private firms and their difference is statistically significant at the $1 \%$ level.

${ }^{14}$ Alternatively, we include several city-level variables such as the natural logarithm of city GDP (GDP), the natural logarithm of city population (Population), the growth of GDP (GDP Growth), and the number of educational institutions in the city (Educational Institutions) as additional controls in our regressions. The empirical results are highly consistent with our current findings. For brevity, the empirical results are not reported but available from the authors. Instead, in our following regressions, we only report results with city and industry dummies as control variables.
} 


\subsection{Base Results}

We first employ the Probit model to explore the potential determinants of a firm's likelihood of investing in R\&D. The probability (likelihood) function of spending on R\&D is expressed as follows:

$\operatorname{Pr}(\mathrm{R} \& \mathrm{D}$ Dummy=1) $=f(X \beta)=f($ Government Helping Hand or Grabbing Hand, Contract Enforcement, Ownership, CEO Appointment, Firm Characteristics, Macro Controls, Industry Controls)

where $f(\cdot)$ is the standard normal cumulative distribution (cdf) in the Probit model, which can be

expressed as $f(z)=\Phi(z)=\int_{-\infty}^{z} \phi(v) d v$, where $\phi(\cdot)$ is the standard normal density.

Firm characteristics are captured by a vector of control variables, which include the number of competitors, firm size, firm age, and access to finance. Macro control is simply city dummy or city GDP, city population, GDP growth, and the number of colleges and institutions within the city.

\section{[Table 5 here]}

The results of the Probit models are presented in Table 5. Columns 1-5 are based on cross-sectional observations in 2002. Columns 6-10 are based on the full sample (years 2000 and 2002) with some time-invariant property rights measures. The table further presents the coefficients and p values based on robust standard errors. Although the correlation matrix indicates that multicollinearity among property rights and ownership and control variables is not a major problem, we include the three groups of variables separately and simultaneously to demonstrate that the main results are robust to alternative specifications. The firm characteristics and city macro environment are controlled for in every specification. The industry dummy variables and year dummy variables are also included. For brevity, the coefficients of the industry dummy and year dummy variables are not reported.

Our results provide strong evidence that both the government helping hand and property rights protection encourage corporate $\mathrm{R} \& \mathrm{D}$. Specifically, the variables related to legal 
environment and contract enforcement are of hypothesized signs, although the coefficient of Contract Upheld is statistically insignificant in the models. Firm managers who express greater faith that their property rights will be protected by the contract and upheld by the legal system tend to be more likely to invest in R\&D. The coefficient of Contract is positive and statistically significant at the $5 \%$ level across all different specifications.

The coefficients of Helping Hand are positive and statistically significant at the $5 \%$ level in all specifications, suggesting that an increase in the helpfulness of government officials results in a higher probability of investing in R\&D. Similarly, the coefficients of Efficient Service are positive and statistically significant in all but one specifications. The aforementioned findings indicate the importance of the government's helping hand and efficient service in determining a firm's R\&D decisions. Firms that express greater confidence in the government's helping hand and efficient service are more likely to invest in R\&D projects. Finally, Informal payments does not have a statistically significant effect on a firm's R\&D decisions. This may be partially due to the very modest size of the informal payments in the sample.

Ownership and control are found to have a great impact on R\&D investment decisions. In contrast to SOEs, private firms and joint ventures are more likely to invest in R\&D projects. As Table 5 shows, the coefficients of Private and Joint Venture are positive and statistically significant in all specifications. Nevertheless, we do not find statistically significant relationship between Foreign Enterprise and the likelihood of corporate R\&D. ${ }^{15}$ The positive relationship between Joint Venture and R\&D incentive (relative to SOEs) is perhaps due to the fact that the domestic partner in a joint venture can learn about the new products, advanced technology, managerial skills that their foreign partners bring into China. Such joint venture specific learning

\footnotetext{
${ }^{15}$ The finding that contract enforcement and private ownership both are positively associated with firm incentive for $R \& D$ is not necessarily inconsistent with the fact that the two variable themselves are negatively correlated with one another, as pointed out in section 3 . Contract enforcement is arguably most crucial for the development of private enterprises. Therefore, improvement in contract enforcement tends to benefit the private enterprises (arguably the most innovative) a lot, including their area of R\&D activity.

Chen and Frank, Is this footnote necessary in response to Referee !'s point about Wenzhou.? This footnote is bit confusing. I suggest to delete it (frank)
} 
helps enhance the firm's capability of innovation. ${ }^{16}$

Alternatively, we use the continuous private and foreign ownership to measure the firm's ownership structure. Based on the non-linear foreign ownership effects found above, we include both the foreign ownership and its squared term to capture the potential non-linear effects. As can be seen from the table, the empirical results based on continuous measures strongly confirm our previous findings. Specifically, we find that private ownership exert a positive and statistically significant impacts on the likelihood of corporate R\&D. Regarding the foreign ownership, we find an inversed U-shape relationship between foreign ownership and the likelihood of corporate R\&D. For brevity, we use the continuous ownership measures the main ownership measures in the empirical tests throughout the paper.

As mentioned earlier, another way the state can use a firm to pursue its goals is to exert control over the firm's management selection process and select top managers who represent the state's interests. Our results in Table 5 show that firms with a government-appointed CEO and those with a government-approved CEO nomination are less likely to invest in R\&D projects. In particular, the coefficients of the variable State-Appointed CEO are negative and statistically significant at the 5\% level in regressions (3)-(5) and marginally significant in regression (10). The coefficients for the variable State-Approved CEO Nomination) are all negative but not statistically significant across different specifications. These evidence suggests that state ownership and control over management reduce a firm's incentive to innovate. While the impact of state ownership on $R \& D$ investment is ambiguous on theoretical grounds (because $R \& D$ investment may or may not help state-owned enterprises fulfill their social objectives and responsibilities), our results show that the effect of state ownership and control is to hinder corporate R\&D in the sample of firms we analyze.

Regarding the control variables, we find that firm size and access to finance both are

\footnotetext{
${ }^{16}$ In fact, joint ventures are an important vehicle for Chinese firms to learn from and hopeful leapfrog foreign investors. See, Kong 2005, for a detailed description of Chinese FDI policy in relation to joint ventures, and Lin and Saggi (2004) for a theoretical discussion of the incentive for R\&D in joint ventures.
} 
positively and significantly associated with the likelihood of a firm's R\&D investment. Consistent with our expectation, firm profitability is also positively associated with the likelihood of a firm’s R\&D investment. Market competition exerts a negative and statistically significant impact on the likelihood of $R \& D$ investment, which is consistent with the Schumpeterian hypothesis ${ }^{17}$. The analyses so far focus on the probability of undertaking R\&D investment. We also explore the relationship between various covariates and the amount of R\&D spending using the Tobit model. The empirical results are mostly consistent with our previous findings in the Probit model. ${ }^{18}$

The coefficients of the Probit models cannot be directly read like those in the OLS regressions. To get some sense of the magnitude of the effects, we estimate the marginal effects evaluated at the means of the independent variables from the regressions. The marginal effect of a dummy variable is calculated as the discrete change in the expected value of the dependent variable as the dummy variable changes from 0 to 1 . We find that the effects of property rights protection on corporate $\mathrm{R} \& \mathrm{D}$ are not only statistically significant but also economically significant. For instance, a firm that receives full support from the government (helping hand = 1) is $6 \%-7 \%$ more likely to invest in $\mathrm{R} \& \mathrm{D}$ than a firm that receives no helping hand (helping hand $=0$ ). A one standard deviation increase in government service efficiency would increase a firm's likelihood of conducting an R\&D project by about 3\%. Signing a contract leads to an $8 \%$ increase in the likelihood of conducting R\&D. Regarding ownership and control variables, Private firms and JVs are $7 \%$ and $8 \%$ more likely to conduct R\&D projects than are SOEs, respectively. Firms with state-approved CEO nominations are 6\% less likely to invest in R\&D projects. For brevity, the marginal effects are not reported in the table but available from the

\footnotetext{
17 City population is positively related to firm's R\&D incentive. The number of local educational institutions also has a positive and statistically significant impact on the likelihood of R\&D incentives, suggesting the potential collaboration between enterprises and educational institutions in R\&D projects. To save the space, these results are not reported.

18 Specifically, we find that contract and contract enforcement exert positive impacts on R\&D spending. Helping Hand and Efficient Service are positively and significantly associated with R\&D spending while Informal payments is negatively associated with R\&D spending though the effect is not statistically significant. In addition, private enterprises tend to invest more in R\&D while firms with a government-appointed CEO tend to invest less in R\&D. For brevity, the empirical results are not reported but are available from the authors upon request.
} 
authors upon request.

\subsection{Instrumental Variable Analysis}

In our study, the potential endogeneity may not be a serious problem because it seems unlikely that an individual firm's R\&D decision and investment will influence the property rights such as government expropriation and contract enforcement. Nevertheless, it is still possible that local government may have different treatments of firms based on their R\&D investment and provide more "helping hands" including specific subsidies to high tech (or R\&D intensive) firms. In this regard, the Helping Hand or Efficient Services may be responding to R\&D effort, which creates potential reverse causality problem. In addition, the potential endogeneity problems can also be caused by omitted fixed effects such as regional or industrial effects. In our analysis, we include the industry and city dummies to capture the unobserved fixed effects and therefore the endogeneity problem caused by omitted fixed effects should be less of a concern. Finally, as argued before, there may also be a possibility that our independent variables may contain measurement errors. To deal with this potential endogeneity and/or measurement problem, we need to use the instrumental variable analysis. However, it is not easy to find the instrumental variables since we have already controlled for many firm characteristics such as ownership, performance, size and age, etc. We therefore try to base the selection of instrumental variables on the recent development economics literature (Reinikka and Svesson, 2006; Fisman and Svesson, 2007). Specifically, Fisman and Svensson (2007) try to overcome the similar endogeneity problems by using industry-location averages as instruments. They point out that if the endogeneity problem is specific to firms, but not industries or locations, then netting out this firm-specific component yields a property right measure that only depends on the underlying characteristics inherent to particular industries and/or locations (Reinikka and Svensson, 2006; Fisman and Svensson, 2007). Following Fisman and Svensson (2007), we instrument for government expropriation measures (i.e. Helping Hand, Efficient Service and Informal payments) and contract enforcement measures (i.e. Contract and Contract Upheld) using location-industry 
averages as instruments.

Furthermore, it has been found in the recent literature that political connections help firms secure favorable regulatory conditions and access to resources (Khwaja and Mian, 2005; Faccio, 2006). In China’s context, Li et al. (2008) find that Communist Party membership helps private entrepreneurs to get access to finance and affords them more confidence in the legal system. The survey contains a question that asks about the Party membership and leadership of the CEO. We therefore use two dummy variables about CEO’s Party leadership (Party secretary or Party deputy secretary) as additional instrumental variables. It is unlikely that the CEO’s party leadership will have direct impact on corporate $\mathrm{R} \& \mathrm{D}$ though it may have indirect impact through its influence on government treatment or contract enforcement. We conduct two tests to assess the appropriateness of the instruments. First, we employ the Hansen test of the overidentifying restrictions, which assess whether the instrumental variables are associated with the dependent variable beyond their effects through expropriation measures and contract enforcement measures or the other explanatory variables (Beck, Demirguc-Kunt and Levine, 2005). We refer to this test as "Overidentifying Test" and report the p-value of the test of the overidentifying restrictions. Failure to reject the null hypothesis implied a failure to reject the validity of the instruments. As can be seen from table 6, we can not reject the null hypothesis that the instruments are valid in all the model specifications. In addition, we conduct an F-test of the excluded exogenous variables in the first-stage regressions. The null hypothesis of the test is that the instruments do not explain cross-sectional differences in expropriation and contract enforcement measures. We reject the null hypothesis at the $1 \%$ level in all model specifications. Along with the other regressors, the instrumental variables explain about $53 \%-62 \%$ of the cross-country variation in potentially endogenous variables. For brevity, we only report the p-values of the F-tests in the last row of table 6. The first-stage regressions are available from the authors upon request. The standard IV Probit and IV Tobit (Newey, 1987) are used and the empirical results are presented in table 6.

[Insert Table 6 here]

As can be seen from table 6, the empirical results are robust to the instrumental variable 
analysis. The coefficients of Helping Hand are positive and are statistically significant in all tobit models. The coefficients of Efficient Service are positive and statistically significant in all but one model specifications. Overall, firms that express greater confidence in the government's helping hand and efficient service delivery are more likely to conduct $R \& D$ and tend to invest more in R\&D. The variable Informal payments is also of the hypothesized sign (i.e., negative), although the coefficient is statistically insignificant.

Similarly, contract enforcement promotes R\&D investment, as indicated by the positive and statistically significant coefficients of Contract and Contract Upheld. Firm managers who express greater faith that their rights will be protected by the contract and upheld by the legal system tend to invest more in $R \& D$ projects,

Also consistent with our previous findings, Private and FIE are more likely to conduct R\&D. Furthermore, private enterprises tend to invest more in $R \& D$. The firms with stateappointed CEOs or state-approved CEO nominations tend to have weaker R\&D incentives. The coefficients of the two relevant variables (State-Appointed CEO and State-Approved CEO Nomination) are of the hypothesized sign, although we only find statistical significance for the first variable. Overall, the results bolster our previous findings that both state ownership and control reduce incentives to pursue $R \& D$.

\subsection{Property Rights Protection and Product and Process Innovations}

As mentioned in Section 2, R\&D investments can lead to product or process innovation. While there are a lot of discussions and analysis of product and process R\&D in the vast literature on industrial innovation (see, e.g., Cohen and Klepper, 1996; Lin, 2004; Lin and Saggi, 2002; Scherer and Ross, 1990; Utterback and Abernathy, 1983), data (whether aggregate or firm level) rarely exist for the two categories of R\&D. Fortunately, our dataset contains such information about Chinese firms. Specifically, the survey contains a question that takes the following form: "What types of innovation have you introduced in your plant since the beginning of 1999?”, The firms are asked to respond to the following five sub-questions by "Yes” or "No": 
“(1) Introduced new products (or services) in existing business; (2) Entered new business line; (3)

New process improvements; (4) New management techniques; (5) New quality controls in production”.

To examine the impacts of property rights protection on the types of $R \& D$ or innovative activities undertaken by the firms, we categorize the five types of innovation activities into product innovation (if the firm answers "Yes" to question (1) or (2)) and process innovation (if the firm answers "Yes" to (3), (4) or (5)) and repeat the analysis. ${ }^{19}$ The empirical results are reported in table 7.

\section{[Insert Table 7 here]}

As can be seen in table 7, property rights protection also exerts significant impacts on product and process innovations. Specifically, we find that Contract is positively and significantly associated with the likelihood of process innovation. Contract Upheld exerts positive and statistically significant impacts on the likelihood of both process and product innovations, suggesting that firm managers who express greater faith that their property rights will be protected by the contract and upheld by the legal system are more likely to invest in (and introduce) both product or process R\&D. Efficient Service is positively associated with the likelihood of process innovation. Regarding ownership and control, firms with greater private ownership are more likely to invest in (and introduce) both product and process innovations; while the firms with government -approved CEOs are less likely to do so. Regarding the control variables, ROS, firm size and firm age take the average value across 1999 to 2002. Average profitability, access to finance and firm size are positively associated with the likelihood of product and process innovations while competition and firm age are negatively associated with the likelihood of product and process innovations. Overall, we find that property rights protection and government grabbing/helping hand both have significant impacts on firms'

\footnotetext{
${ }^{19}$ We thank a referee for suggesting considering the types of R\&D activity.
} 
decisions in both types of $R \& D$, which are consistent with our previous findings on total $R \& D$ spendings.

\subsection{Property Rights Protection and R\&D: Split Sample Analysis}

Cull and $\mathrm{Xu}$ (2005) find that property rights protection and access to finance exerts impacts on reinvestment rate only for the relatively smaller firms. For relatively larger firms, they do not find any statistically significant relationship between property rights protection, access to finance and corporate reinvestment rate. To test whether the relationship between

property rights and corporate $R \& D$ varies across firms with different sizes, we split the sample into large (firm size above sample median) and small (firm size below sample median) firms and repeat the analysis. The empirical results can be found in table 8.

[Insert Table 8 here]

Unlike the findings in Cull and $\mathrm{Xu}$ (2005), property rights protection matters in both large and small firms. As can be seen from the table, Contract exerts positive and statistically significant impacts on the likelihood of investing in R\&D for both large and small firms. We find a positive effect of Contract Upheld on the likelihood of investing in R\&D in small firms. The effect, however, is not statistically significant in large firms. Regarding the expropriation measures, $R \& D$ decisions in large firms are more sensitive to the efficiency of government service, as indicated by the positive and statistically significant coefficients of Efficient Service; while the $R \& D$ decisions in small firms are more sensitive to government helping hand (Helping Hand) and grabbing hand (Informal Payment), suggesting that small firms tend to be more fearful of expropriation than large firms. This finding echoes that of Cull and $\mathrm{Xu}$ (2005), who find that informal payment is negatively associated with reinvestment rate only in small firms. The effects of ownership and control are significant only in large firms. For large firms, we find (1) a positive link between private ownership and the likelihood of corporate $R \& D$ and an inversed U-shape relationship between foreign ownership and the likelihood of corporate R\&D. In addition, we find that large firms with CEO approved or appointed by government are less 
likely to invest in R\&D. Unlike the findings in Cull and Xu (2005), the effects of ownership and control are not statistically significant in small firms. The results suggest that the politically connected CEOs in large companies have more concerns about their political career and are therefore more willing to gain the political credit and maximize their careers and their movement up the political hierarchy. In contrast, CEOs in small firms might have more concerns about the operation and economic performance of the enterprises and consequently the effects of ownership and control are not statistically significant in small firms.

\section{Concluding Remarks}

In this paper, we examine the effects of property rights protection and government services on corporate R\&D, using an unique World Bank survey data on 2,400 firms in 18 Chinese cities in 2003. The survey data provide detailed information on firm R\&D, managers' perceived degree of property rights protection and the service quality of local governments, as well as firm ownership and financial data. We find that (1) property rights protection in terms of contract enforcement plays an essential role in promoting corporate $\mathrm{R} \& \mathrm{D}$ (in terms of both the decision to engage in R\&D and its intensity); (2) when the government extends a helping hand and provides efficient services to corporations, it promotes a firm's innovative activities; by contrast, when the government engages in expropriation of firm profits, firm $\mathrm{R} \& \mathrm{D}$ is discouraged; and (3) direct government ownership of a firm and intervention in CEO appointments do not facilitate corporate R\&D.

Our study is among the first attempts to examine empirically the effects of property rights protection on $R \& D$ and economic development. It contributes to the recent emerging literature that emphasizes the importance of economic institutions in explaining differences in economic growth among countries. It also adds to the vast literature on R\&D which has focused mostly on intellectual property rights protection. An important policy implication for developing countries is that establishing a modern system of property rights protection and contract enforcement is vital to $\mathrm{R} \& \mathrm{D}$ and long term economic growth. 


\section{References:}

Acemoglu, Daron, Simon Johnson and James A. Robinson, 2002, "Reversal of Fortune: Geography and Institutions in the Making of the Modern World Income Distribution,” Quarterly Journal of Economics, 118, 1231-1294.

Acemoglu, Daron, Simon Johnson and James A. Robinson, 2005, Institutions as the Fundamental Cause of Long-run Economic Growth,” in Philippe Aghion and Stephen Durlauf, eds., Handbook of Economic Growth, North Holland

Allen, F., Qian, J., and Qian, M., 2005, "Law, Finance, and Economic Growth in China." Journal of Financial Economics, 77, 57-116.

Argyes, N. S., and Silverman, B. S., 2004, "R\&D, Organization Structure, and the Development of Corporate Technological Knowledge.” Strategic Management Journal, 25, 929-958.

Atkinson, A. B., and Stiglitz, J., 1980, Lectures on Public Economics. London: McGraw Hill.

Ayyagari, M., Demirguc-Kunt, A., Maksimovi, V., 2007. How well do institutional theories explain firms’ perceptions of property rights? Review of Financial Studies, forthcoming.

Barro, R., 1990, "Economic Growth in a Cross Section of Countries.” Quarterly Journal of Economics 106: 407-33.

Beck, Thorsten, Asli Demirguc-Kunt, and Vojislav Maksimovic, 2005, "Financial and legal constraints to firm growth: Does size matter?” Journal of Finance 60, 137-177.

Beck, Thorsten, Asli Demirguc-Kunt, and Ross Levine, 2005, “ SMEs, Growth, and Poverty: Cross-Country Evidence,” Journal of Economic Growth 10, 199-229.

Beck, Thorsten, Asli Demirguc-Kunt, and Ross Levine, 2006, "Bank supervision and corruption in lending.” Journal of Monetary Economics 53, 2131-2163.

Besley, T., 1995, "Property Rights and Investment Incentives: Theory and Evidence from Ghana.” Journal of Political Economy, 103(5), 903-37.

Branstetter, L. G., Fisman, R., and Foley, C. F., 2006, “Do Stronger Intellectual Property Rights Increase International Technology Transfer? Empirical Evidence from U.S. Firm-Level Panel Data.” Quarterly Journal of Economics, 121, 321-349.

Chen, Y., and Puttitanun, T., 2005, "Intellectual Property Rights and Innovation in Developing Countries.” Journal of Development Economics, 78(2), 474-493.

Claessens, Stijin, and Luc Laeven, 2003, Financial development, property rights, and growth, Journal of Finance 58, 2401-2435.

Cohen, W.M., Klepper, S., 1996. Firm size and the nature of innovation within industries: The case of process and product R\&D. Review of Economics and Statistics 78, 232$\} 243$. 
Cull, R., and Xu, L., 2005, "Institutions, Ownership, and Finance: The Determinants of Profit Reinvestment Among Chinese Firms.” Journal of Financial Economics, 77, 117-146.

Demirguc-Kunt, A., Maksimovic, V., 1998. “Law, Finance, and Firm Growth.” Journal of Finance 53, 2107- 2137.

Djankov, S., La Porta, R., Lopez-De-Silanes, F., Shleifer, A., 2003. “Courts,” Quarterly Journal of Economics, 119, 453-517.

Faccio, M., 2006, “Politically Connected Firms.” American Economic Review 96, 1, 369-386.

Fisman, R., and Svensson, J., 2007, “Are corruption and taxation really harmful to growth? Firm level evidence,” Journal of Development Economics, 83, 63-75.

Glass, A.J., and K. Saggi, 2002, “Intellectual Property Rights and the Foreign Direct Investment.” Journal of International Economics 56, 387-410.

Grossman, G., and Helpman, E., 1991, “Quality Adders and Product Cycles,” Quarterly Journal of Economics, 106, 557-586.

Helpman, E., 1993, “Innovation, Imitation, and Intellectual Property Rights.” Econometrica, 61(6), 1247-1280.

Hu, A., and Jefferson, G., 2004, "Returns to Research and Development in Chinese Industry: Evidence from State-owned Enterprises in Beijing.” China Economic Review, 15, 86-107.

Hu, A., Jefferson, G., and Qian, J., 2005, “R\&D and Technology Transfer: Firm Level Evidence from Chinese Industry.” Review of Economics and Statistics, 87, 780-786.

Huang, Y., 2003, Selling China: Foreign Direct Investment During the Reform ERA, Cambridge University Press, London, UK.

Jefferson, G., and Rawski, T., 2002, “China's Emerging Markets for Property Rights: Theoretical and Empirical Perspectives.” Economic of Transition, 10, 585-617.

Johnson, S., McMillan, J., and Woodruff, C., 2002, "Property Rights and Finance.” American Economic Review, 92(5), 1335-1356.

Keefer, Philip and Stephen Knack 1997, "Why Don't Poor Countries Catch Up? A CrossCountry Test of an Institutional Explanation.” Economic Inquiry 35(3): 590-602.

Khuaja, A., and Mian, A., 2005. Do Lenders Favor Politically Connected Firms? Rent Provision in an Emerging Financial Market.” Quarterly Journal of Economics, 120, 1371-1411. 
King, R.G., and R. Levine, 1993. "Finance and Growth: Schumpeter Might Be Right.” Quarterly Journal of Economics, 108, 717-738.

Knack, Stephen and Philip Keefer, 1995, "Institutions and Economic Performance: CrossCountry Tests Using Alternative Institutional Measures.” Economics and Politics 7: 207-27.

Kong, 2005.

La Porta, R., López de Silanes, F., Shleifer, A., Vishny, R., 1998. “Law and Finance,” Journal of Political Economy, 106(6), 1113-1155.

La Porta, R., López de Silanes, F., Shleifer, A., and Vishny, R., 2002. "Investor Protection and Corporate Valuation,” Journal of Finance, 62, 1147-1170.

La Porta, R., López de Silanes, F., Pop-Eleches, C., and Shleifer, A., 2004, “Judicial Checks and Balances.” Journal of Political Economy, 112, 445-470.

Levine, Ross, 2005, Law, endowments, and property rights, Journal of Economic Perspectives 19, 61-88..

Li, H., and Zhou, L.-A., 2005, "Political Turnover and Economic Performance: The Incentive Role of Personnel Control in China.” Journal of Public Economics, 89, 1743-1762.

Li, H., Meng, L., Wang, Q., and Zhou, L.-A., 2008, "Political Connections, Financing and Firm Performance: Evidence from Chinese Private Firms.” Journal of Development Economics, forthcoming.

Lin, Ping, 2004, "Process and Product R\&D by a Multi-product Monopolist," Oxford Economic Papers, 56, 2004, 735-43.

Lin, Ping and Kamal Saggi, 2002, "Product Innovation, Process R\&D, and the Nature of Market Competition.” European Economic Review, 46 (1), 201-211.

Lin, Ping and Kamal Saggi, 2004, “ Optimal Ownership Structure and Technological Upgrading in Joint Ventures, Review of Development Economics, 8(2), May 2004, 279-294.

Lucas, Robert E.,1988), “On the Mechanics of Economic Development,” Journal of Monetary Economics, 22, 3-42.

Mauro, Paolo (1995). “Corruption and Growth.” Quarterly Journal of Economics, 110, 681-712.

McMillan, J., and Woodruff, C., 2002, "The Central Role of Entrepreneurs in Transitional Economies.” Journal of Economic Perspectives, 16(3), 153-170. 
Megginson, W., 2005, The Financial Economics of Privatization. Oxford: Oxford University Press.

Newey, W. K., 1987. "Efficient estimation of limited dependent variable models with endogenous explanatory variables," Journal of Econometrics, 36, 231-250.

Nickell, S., 1996, “Competition and Corporate Performance.” Journal of Political Economy, 104, 724-746.

North, D., 1990. Institutions, Institutional Change and Economic Performance. Cambridge: Cambridge University Press.

Porter, M., 1990, The Competitive Advantage of Nations. New York: Free Press.

Reinnikka, R. and Svensson, J., 2006, "Using Micro-Surveys to Measure and Explain Corruption”, World Development, 34, 359-370.

Romer, P. M., 1986, “Increasing Returns and Long-Run Growth,” Journal of Political Economy, 94, 1002-1037.

Romer, P. M., 1990, “Endogenous Technical Change,” Journal of Political Economy, 98, 71-102.

Scherer, F.M., Ross, D., 1990. Industrial Market Structure and Economics Performance. Houghton Mifflin, Boston, MA.

Scherer, F. M., 1992, “Schumpeter and Plausible Capitalism,” Journal of Economic Literature, 30, 1416-1434.

Shleifer, A. and R. W. Vishy, 1993, "Corruption,” Quarterly Journal of Economics, 108, 599617.

Shleifer, A., and Vishny, R., 1994, "Politicians and Firms.” Quarterly Journal of Economics, 109, 995-1025.

Shleifer, A., and Vishny, R., 1997, “A Survey of Corporate Governance.” Journal of Finance, 52, 737-777.

Solow, Robert M., 1956, “A Contribution to the Theory of Economic Growth,” Quarterly Journal of Economics, 70, 65-94.

Tassey, G., 1991, "The Functions of Technology Infrastructure in a Competitive Economy.” Research Policy, 20, 345-361.

Utterback, J.M., Abernathy, W.J., 1983. "A dynamic model of process and product innovation.” Omega 3 (6), 639-656. 
Table 1: Summary Statistics of Main Variables

\begin{tabular}{|c|c|c|c|c|c|}
\hline Variable & Observations & Mean & $\begin{array}{l}\text { Standard } \\
\text { deviation }\end{array}$ & Minimum & Maximum \\
\hline \multicolumn{6}{|l|}{ Firm Level Variables } \\
\hline \multicolumn{6}{|l|}{ R\&D Decision Dummy } \\
\hline (=1 if firm conducted $R \& D$ ) & 2373 & 0.251 & 0.434 & 0 & 1 \\
\hline R\&D Intensity & 2373 & 0.006 & 0.03 & 0 & 0.705 \\
\hline $\begin{array}{l}\text { Contract (Dummy: sign formal contract) } \\
\text { Contract Upheld (likelihood that legal system }\end{array}$ & 2373 & 0.883 & 0.321 & 0 & 1 \\
\hline will uphold contract and property rights) & 2068 & 0.64 & 0.389 & 0 & 1 \\
\hline $\begin{array}{l}\text { Helping Hand } \\
\text { (government officials help rather than } \\
\text { hinder) }\end{array}$ & 2225 & 0.343 & 0.314 & 0 & 1 \\
\hline \multicolumn{6}{|l|}{ Informal payments to government officials } \\
\hline $\begin{array}{l}\text { (\% of sales ) } \\
\text { Efficient Service } \\
\text { (share of government officials that deliver }\end{array}$ & 2174 & 0.024 & 0.072 & 0 & 0.81 \\
\hline efficient service) & 2168 & 0.355 & 0.333 & 0 & 1 \\
\hline Dummy: Private Firm & 2375 & 0.383 & 0.486 & 0 & 1 \\
\hline Dummy: Foreign-Invested Enterprise (FIE) & 2274 & 0.103 & 0.304 & 0 & 1 \\
\hline Private Ownership & 2399 & 0.430 & 0.471 & 0 & 1 \\
\hline Foreign Ownership & 2399 & 0.079 & 0.233 & 0 & 1 \\
\hline Dummy: State-Appointed CEO & 2367 & 0.124 & 0.329 & 0 & 1 \\
\hline Dummy: State-Approved CEO Nomination & 2400 & 0.133 & 0.340 & 0 & 1 \\
\hline Competition (categories $1-5$ ) & 2326 & 3.822 & 1.354 & 1 & 5 \\
\hline Access to Finance (access to bank loans) & 2333 & 0.254 & 0.435 & 0 & 1 \\
\hline Firm Size (log employee number) & 2396 & 4.85 & 1.491 & 0 & 11.159 \\
\hline Lagged ROS & 2304 & 0.138 & 0.226 & -1.998 & 0.997 \\
\hline Firm Age & 2400 & 14.986 & 14.39 & 2 & 52 \\
\hline
\end{tabular}

Note: The summary statistics are based on the observations in year 2002. 
Table 2: R\&D across Cities

\begin{tabular}{lccc}
\hline City & Share of firms conducting R\&D & R\&D intensity & $\begin{array}{c}\text { R\&D intensity (for firms } \\
\text { with positive R\&D } \\
\text { expenditures) }\end{array}$ \\
\hline Benxi & 0.1 & 0.001 & 0.013 \\
Changchun & 0.360 & 0.01 & 0.027 \\
Changsha & 0.253 & 0.006 & 0.023 \\
Chongqing & 0.450 & 0.13 & 0.028 \\
Dalian & 0.210 & 0.006 & 0.029 \\
Guiyang & 0.227 & 0.004 & 0.018 \\
Haerbin & 0.200 & 0.01 & 0.047 \\
Hangzhou & 0.510 & 0.009 & 0.019 \\
Jiangmen & 0.185 & 0.002 & 0.012 \\
Kunming & 0.153 & 0.003 & 0.017 \\
Lanzhou & 0.088 & 0.0004 & 0.005 \\
Nanchang & 0.250 & 0.005 & 0.022 \\
Nanning & 0.174 & 0.004 & 0.023 \\
Shenzhen & 0.270 & 0.004 & 0.013 \\
Wenzhou & 0.210 & 0.002 & 0.011 \\
Wuhan & 0.346 & 0.008 & 0.024 \\
Xi'an & 0.350 & 0.007 & 0.021 \\
Zhengzhou & 0.173 & 0.005 & 0.029 \\
\hline
\end{tabular}


Table 3: Property Rights, Ownership, and Government Control across Cities

\begin{tabular}{|c|c|c|c|c|c|c|c|c|c|}
\hline City & $\begin{array}{l}\text { Helping } \\
\text { Hand }\end{array}$ & $\begin{array}{l}\text { Efficient } \\
\text { Service }\end{array}$ & $\begin{array}{l}\text { Informal } \\
\text { payments }\end{array}$ & Contract & $\begin{array}{l}\text { Contract } \\
\text { Upheld }\end{array}$ & $\begin{array}{c}\text { Private } \\
\text { Ownership }\end{array}$ & $\begin{array}{l}\text { Foreign } \\
\text { Ownership }\end{array}$ & $\begin{array}{l}\text { State- } \\
\text { Appointed } \\
\text { CEO }\end{array}$ & $\begin{array}{c}\text { State- } \\
\text { Approved } \\
\text { CEO } \\
\text { Nomination }\end{array}$ \\
\hline Benxi & 0.284 & 0.208 & 0.028 & 0.727 & 0.526 & 0.311 & 0.012 & 0.070 & 0.220 \\
\hline Changchun & 0.448 & 0.368 & 0.013 & 0.947 & 0.695 & 0.389 & 0.090 & 0.107 & 0.160 \\
\hline Changsha & 0.332 & 0.268 & 0.021 & 0.906 & 0.504 & 0.542 & 0.053 & 0.182 & 0.113 \\
\hline Chongqing & 0.409 & 0.549 & 0.023 & 0.920 & 0.860 & 0.415 & 0.088 & 0.080 & 0.100 \\
\hline Dalian & 0.234 & 0.356 & 0.018 & 0.939 & 0.574 & 0.250 & 0.254 & 0.113 & 0.140 \\
\hline Guiyang & 0.226 & 0.221 & 0.020 & 0.877 & 0.561 & 0.401 & 0.016 & 0.190 & 0.133 \\
\hline Haerbin & 0.474 & 0.437 & 0.024 & 0.852 & 0.686 & 0.275 & 0.040 & 0.127 & 0.213 \\
\hline Hangzhou & 0.498 & 0.515 & 0.013 & 0.948 & 0.720 & 0.450 & 0.174 & 0.070 & 0.100 \\
\hline Jiangmen & 0.535 & 0.381 & 0.017 & 0.910 & 0.574 & 0.401 & 0.267 & 0.071 & 0.220 \\
\hline Kunming & 0.343 & 0.367 & 0.038 & 0.813 & 0.689 & 0.398 & 0.036 & 0.154 & 0.173 \\
\hline Lanzhou & 0.237 & 0.217 & 0.042 & 0.849 & 0.479 & 0.357 & 0.068 & 0.221 & 0.160 \\
\hline Nanchang & 0.373 & 0.468 & 0.021 & 0.893 & 0.795 & 0.401 & 0.066 & 0.177 & 0.127 \\
\hline Nanning & 0.212 & 0.241 & 0.025 & 0.886 & 0.528 & 0.490 & 0.038 & 0.139 & 0.087 \\
\hline Shenzhen & 0.367 & 0.408 & 0.020 & 0.919 & 0.766 & 0.393 & 0.147 & 0.031 & 0.060 \\
\hline Wenzhou & 0.206 & 0.211 & 0.013 & 0.879 & 0.422 & 0.877 & 0.031 & 0.020 & 0.050 \\
\hline Wuhan & 0.325 & 0.350 & 0.033 & 0.953 & 0.666 & 0.483 & 0.077 & 0.087 & 0.100 \\
\hline Xian & 0.279 & 0.308 & 0.026 & 0.893 & 0.551 & 0.375 & 0.050 & 0.167 & 0.113 \\
\hline Zhengzhou & 0.364 & 0.431 & 0.024 & 0.793 & 0.819 & 0.568 & 0.044 & 0.107 & 0.120 \\
\hline
\end{tabular}


Table 4: Correlation Matrix of Firm Level Variables

\begin{tabular}{|c|c|c|c|c|c|c|c|c|c|c|c|c|c|c|c|c|c|}
\hline & & 1 & 2 & 3 & 4 & 5 & 6 & 7 & 8 & 9 & 10 & 11 & 12 & 13 & 14 & 15 & 16 \\
\hline 1 & $R \& D$ & 1 & & & & & & & & & & & & & & & \\
\hline 2 & Helping Hand & $0.1167^{*}$ & 1 & & & & & & & & & & & & & & \\
\hline 3 & Efficient Service & $0.1118 *$ & $0.3928 *$ & 1 & & & & & & & & & & & & & \\
\hline 4 & Expropriation & -0.0088 & $-0.1090 *$ & -0.0262 & 1 & & & & & & & & & & & & \\
\hline 5 & Contract & $0.1345^{*}$ & 0.0324 & 0.0036 & 0.0112 & 1 & & & & & & & & & & & \\
\hline 6 & Contract Upheld & $0.0711^{*}$ & $0.2572 *$ & $0.3112^{*}$ & -0.006 & 0.0346 & 1 & & & & & & & & & & \\
\hline 7 & State Ownership & -0.0329 & 0.0098 & 0.0198 & 0.0149 & $-0.0695 *$ & $0.0507 *$ & 1 & & & & & & & & & \\
\hline 8 & Private Ownership & -0.0224 & 0.0046 & -0.0242 & 0.008 & $0.0646^{*}$ & -0.0352 & $-0.4756^{*}$ & & & & & & & & & \\
\hline 9 & Foreign Ownership & $0.1002 *$ & $0.0615^{*}$ & $0.0592 *$ & -0.0399 & 0.037 & 0.0129 & $-0.1673 *$ & $-0.2647 *$ & & & & & & & & \\
\hline 10 & State Appointed CEO & $-0.0600 *$ & -0.0085 & -0.0138 & -0.0277 & $-0.0712 *$ & 0.0072 & $0.3949 *$ & $-0.2639 *$ & $-0.1024 *$ & & & & & & & \\
\hline 11 & State Approved CEO & $-0.0436 *$ & 0.0125 & -0.0035 & $0.0465 *$ & $-0.0483^{*}$ & 0.0124 & $0.1566 *$ & $-0.1794 *$ & $-0.0894 *$ & $-0.1483^{*}$ & 1 & & & & & \\
\hline 12 & Lag ROS & $0.0487 *$ & -0.0006 & -0.0049 & -0.0155 & 0.0135 & -0.0043 & -0.0355 & 0.0029 & 0.0109 & $-0.0466^{*}$ & -0.0216 & 1 & & & & \\
\hline 13 & Competition & $-0.2477^{*}$ & $-0.0602 *$ & -0.0363 & 0.0022 & $-0.0441^{*}$ & 0.0267 & -0.0048 & $0.0883^{*}$ & $-0.1134 *$ & $0.0600 *$ & -0.0097 & $-0.0493 *$ & 1 & & & \\
\hline 14 & Access to Finance & $0.2161^{*}$ & $0.0442 *$ & 0.0214 & 0.0176 & $0.0674^{*}$ & $0.0741^{*}$ & $0.0432 *$ & 0.0004 & $0.0491^{*}$ & 0 & -0.0233 & 0.0369 & $-0.0794^{*}$ & 1 & & \\
\hline 15 & Firm Size & 0.3199* & $0.0860 *$ & $0.0776^{*}$ & -0.0049 & $0.1198 *$ & $0.1177^{*}$ & $0.2305^{*}$ & $-0.2685 *$ & $0.1114^{*}$ & $0.1350 *$ & 0.0106 & -0.0398 & $-0.2115^{*}$ & $0.3137^{*}$ & & \\
\hline 16 & Firm Age & -0.0178 & -0.0327 & -0.0328 & $0.0592 *$ & $-0.0702 *$ & 0.0052 & $0.4292 *$ & $-0.3703^{*}$ & $-0.1570 *$ & $0.3043^{*}$ & $0.2096 *$ & $-0.0752 *$ & 0.0141 & $0.0628 *$ & $0.3124 *$ & 1 \\
\hline
\end{tabular}

Note: * indicate significance at $5 \%$. 
Table 5: Probit Regressions on R\&D Decisions

\begin{tabular}{|c|c|c|c|c|c|c|c|c|c|c|}
\hline & & & Year 2002 & & & & & Full Sample & & \\
\hline Specification & $(1)$ & $(2)$ & (3) & $(4)$ & (5) & (6) & $(7)$ & $(8)$ & (9) & $(10)$ \\
\hline \multicolumn{11}{|l|}{ Contract Enforcement } \\
\hline \multirow[t]{2}{*}{ Contract } & 0.347 & & & & 0.329 & 0.327 & & & & 0.314 \\
\hline & {$[0.016]^{* *}$} & & & & {$[0.027]^{* *}$} & {$[0.013]^{* *}$} & & & & {$[0.021]^{* *}$} \\
\hline \multirow[t]{2}{*}{ Contract Upheld } & 0.065 & & & & 0.006 & 0.112 & & & & 0.072 \\
\hline & [0.518] & & & & [0.957] & [0.247] & & & & [0.493] \\
\hline \multicolumn{11}{|l|}{$\begin{array}{l}\text { Government } \\
\text { Expropriation }\end{array}$} \\
\hline \multirow[t]{2}{*}{ Helping Hand } & & 0.275 & & & 0.294 & & 0.27 & & & 0.261 \\
\hline & & {$[0.033]^{* *}$} & & & {$[0.035]^{* *}$} & & {$[0.028]^{* *}$} & & & {$[0.048]^{* *}$} \\
\hline \multirow[t]{2}{*}{ Efficient Service } & & 0.283 & & & 0.288 & & 0.196 & & & 0.172 \\
\hline & & {$[0.023]^{* *}$} & & & {$[0.031]^{* *}$} & & {$[0.099]^{*}$} & & & {$[0.174]$} \\
\hline \multirow[t]{2}{*}{ Informal payments } & & 0.143 & & & 0.117 & & -0.081 & & & -0.072 \\
\hline & & {$[0.767]$} & & & {$[0.817]$} & & {$[0.864]$} & & & {$[0.883]$} \\
\hline \multicolumn{11}{|l|}{ Ownership \& Control } \\
\hline \multirow[t]{2}{*}{ Private } & & & 0.249 & & & & & 0.286 & & \\
\hline & & & {$[0.003]^{* * *}$} & & & & & {$[0.003]^{* * *}$} & & \\
\hline \multirow[t]{2}{*}{ Foreign Enterprise } & & & -0.103 & & & & & 0.027 & & \\
\hline & & & [0.619] & & & & & [0.902] & & \\
\hline \multirow[t]{2}{*}{ Joint Venture } & & & 0.27 & & & & & 0.403 & & \\
\hline & & & {$[0.022]^{* *}$} & & & & & {$[0.002]^{* * *}$} & & \\
\hline \multirow[t]{2}{*}{ Private Ownership } & & & & 0.196 & 0.189 & & & & 0.181 & 0.186 \\
\hline & & & & {$[0.035]^{* *}$} & {$[0.082]^{*}$} & & & & {$[0.042]^{* *}$} & {$[0.068]^{*}$} \\
\hline \multirow[t]{2}{*}{ Foreign Ownership } & & & & 1.426 & 1.305 & & & & 1.293 & 1.161 \\
\hline & & & & {$[0.010]^{* *}$} & {$[0.036]^{* *}$} & & & & {$[0.014]^{* *}$} & {$[0.049]^{* *}$} \\
\hline \multirow[t]{2}{*}{ Foreign Ownership ${ }^{2}$} & & & & -1.557 & -1.426 & & & & -1.441 & -1.261 \\
\hline & & & & {$[0.012]^{* *}$} & {$[0.040]^{* *}$} & & & & {$[0.015]^{* *}$} & {$[0.057]^{*}$} \\
\hline
\end{tabular}




\begin{tabular}{|c|c|c|c|c|c|c|c|c|c|c|}
\hline \multicolumn{3}{|l|}{ State-Appointed CEO } & $\begin{array}{l}-0.255 \\
{[0.039]^{* *}}\end{array}$ & $\begin{array}{l}-0.264 \\
{[0.031]^{* *}}\end{array}$ & $\begin{array}{l}-0.343 \\
{[0.017]^{* *}}\end{array}$ & & & $\begin{array}{l}-0.083 \\
{[0.522]}\end{array}$ & $\begin{array}{l}-0.18 \\
{[0.118]}\end{array}$ & $\begin{array}{l}-0.237 \\
{[0.071]^{*}}\end{array}$ \\
\hline \multicolumn{3}{|l|}{ State-Approved CEO } & -0.104 & -0.103 & -0.12 & & & -0.091 & -0.089 & -0.106 \\
\hline \multicolumn{3}{|l|}{ Nomination by firm } & {$[0.330]$} & {$[0.335]$} & {$[0.317]$} & & & {$[0.441]$} & {$[0.396]$} & {$[0.375]$} \\
\hline \multicolumn{11}{|l|}{ Other Controls } \\
\hline \multirow[t]{2}{*}{ Lagged ROS } & 0.575 & 0.583 & 0.488 & 0.481 & 0.634 & 0.225 & 0.237 & 0.197 & 0.2 & 0.23 \\
\hline & {$[0.001] * * *$} & {$[0.000] * * *$} & {$[0.002] * * *$} & {$[0.002] * * *$} & {$[0.000] * * *$} & {$[0.001] * * *$} & {$[0.001]^{* * *}$} & {$[0.010] * * *$} & {$[0.003] * * *$} & {$[0.002]^{* * *}$} \\
\hline \multirow[t]{2}{*}{ Competition } & -0.109 & -0.089 & -0.09 & -0.082 & -0.1 & -0.102 & -0.078 & -0.079 & -0.076 & -0.092 \\
\hline & {$[0.000]^{* * *}$} & {$[0.001] * * *$} & {$[0.001]^{* * *}$} & {$[0.001] * * *$} & {$[0.001]^{* * *}$} & {$[0.000]^{* * *}$} & {$[0.003]^{* * *}$} & {$[0.004]^{* * *}$} & {$[0.002]^{* * *}$} & {$[0.001]^{* * *}$} \\
\hline \multirow[t]{2}{*}{ Access to Finance } & 0.276 & 0.269 & 0.246 & 0.239 & 0.258 & 0.268 & 0.263 & 0.271 & 0.237 & 0.251 \\
\hline & {$[0.001] * * *$} & {$[0.001]^{* * *}$} & {$[0.001] * * *$} & {$[0.002]^{* * *}$} & {$[0.003] * * *$} & {$[0.001]^{* * *}$} & {$[0.001]^{* * *}$} & {$[0.001] * * *$} & {$[0.001]^{* * *}$} & {$[0.003]^{* * *}$} \\
\hline \multirow[t]{2}{*}{ Firm Size } & 0.331 & 0.306 & 0.351 & 0.346 & 0.337 & 0.286 & 0.267 & 0.277 & 0.303 & 0.29 \\
\hline & {$[0.000] * * *$} & {$[0.000]^{* * *}$} & {$[0.000]^{* * *}$} & {$[0.000] * * *$} & {$[0.000]^{* * *}$} & {$[0.000]^{* * *}$} & {$[0.000]^{* * *}$} & {$[0.000]^{* * *}$} & {$[0.000]^{* * *}$} & {$[0.000]^{* * *}$} \\
\hline \multirow[t]{2}{*}{ Firm Age } & -0.011 & -0.01 & -0.006 & -0.006 & -0.006 & -0.011 & -0.009 & -0.003 & -0.006 & -0.006 \\
\hline & {$[0.000]^{* * *}$} & {$[0.000] * * *$} & {$[0.055]^{*}$} & {$[0.056]^{*}$} & {$[0.088]^{*}$} & {$[0.000] * * *$} & {$[0.000]^{* * *}$} & {$[0.345]$} & {$[0.026]^{* *}$} & {$[0.060]^{*}$} \\
\hline City Dummy & yes & yes & yes & yes & yes & yes & yes & yes & yes & yes \\
\hline Industry Dummy & yes & yes & yes & yes & yes & yes & yes & yes & yes & yes \\
\hline Year Dummy & yes & yes & yes & yes & yes & yes & yes & yes & yes & yes \\
\hline \multirow[t]{2}{*}{ Constant } & -2.403 & -2.248 & -2.526 & -2.523 & -2.834 & -2.209 & -2.05 & -2.229 & -2.317 & -2.542 \\
\hline & {$[0.000]^{* * *}$} & {$[0.000]^{* * *}$} & {$[0.000]^{* * *}$} & {$[0.000] * * *$} & {$[0.000]^{* * *}$} & {$[0.000]^{* * *}$} & {$[0.000]^{* * *}$} & {$[0.000] * * *$} & {$[0.000]^{* * *}$} & {$[0.000]^{* * *}$} \\
\hline Observations & 1894 & 1823 & 2144 & 2164 & 1673 & 3704 & 3569 & 3354 & 4230 & 3280 \\
\hline
\end{tabular}

Note: The regressions are run with probit, which is based on standard maximum likelihood estimation with heteroskedasticity-robust standard errors clustering within firms. ***, **, * indicate significance at the $1 \%, 5 \%$ and $10 \%$ levels, respectively. P-values based on robust standard errors are in parentheses. 
Table 6: Property Rights and R\&D: Instrumental Variable Analysis

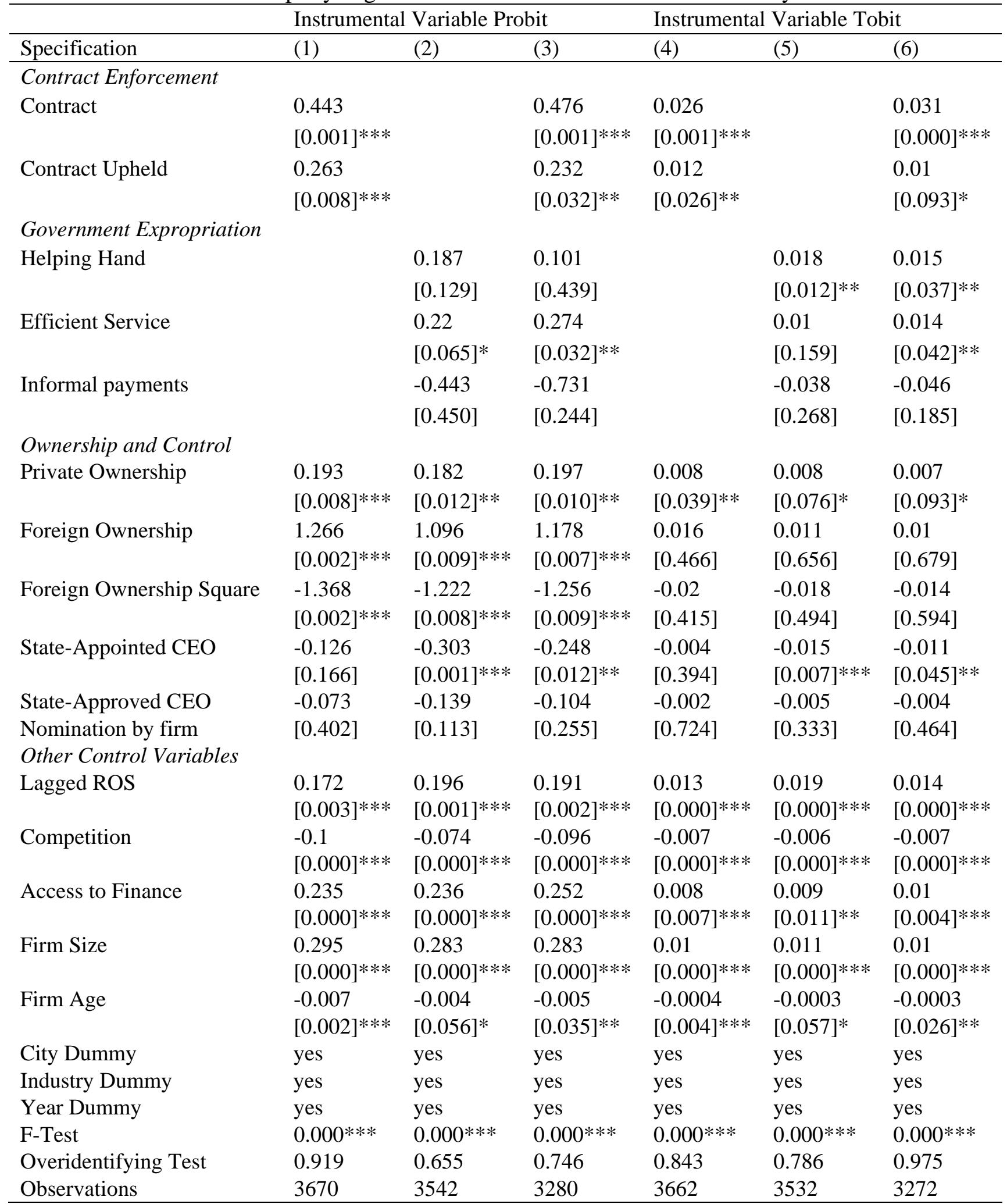

Note: $* * *, * *, *$ indicate significance at $1 \%, 5 \%$, and $10 \%$, respectively. P-values are in parentheses. Following Fisman and Svensson (2007), the instruments are industry-location average of the potentially endogenous variables (Helping Hand, Efficient Service, Informal payments, Contract and Contract Upheld). In addition, the Communist Party leadership of the CEO (Party Secretary or Party Deputy Secretary) are used as additional instrumental variables. Columns (1) to (3) are based on IV Probit estimation. Columns (4) to (6) are based on IV Tobit estimation. The estimation results are based on the pooled sample. The cross sectional sample in year 2002 yield very similar results. 
Table 7: Probit Models for Process R\&D and Product R\&D

\begin{tabular}{|c|c|c|c|c|}
\hline \multirow[b]{2}{*}{ Specification } & \multicolumn{2}{|c|}{ Product R\&D } & \multicolumn{2}{|c|}{ Process R\&D } \\
\hline & $(1)$ & $(2)$ & (3) & $(4)$ \\
\hline \multicolumn{5}{|l|}{ Contract Enforcement } \\
\hline Contract & $\begin{array}{l}0.126 \\
{[0.239]}\end{array}$ & $\begin{array}{l}0.114 \\
{[0.313]}\end{array}$ & $\begin{array}{l}0.34 \\
{[0.001]^{* * *}}\end{array}$ & $\begin{array}{l}0.355 \\
{[0.001]^{* * *}}\end{array}$ \\
\hline Contract Upheld & $\begin{array}{l}0.199 \\
{[0.022]^{* *}}\end{array}$ & $\begin{array}{l}0.23 \\
{[0.016]^{* *}}\end{array}$ & $\begin{array}{l}0.176 \\
{[0.041]^{* *}}\end{array}$ & $\begin{array}{l}0.149 \\
{[0.118]}\end{array}$ \\
\hline \multicolumn{5}{|l|}{ Government Expropriatio } \\
\hline Helping Hand & & $\begin{array}{l}0.002 \\
{[0.983]}\end{array}$ & & $\begin{array}{l}-0.011 \\
{[0.930]}\end{array}$ \\
\hline Efficient Service & & $\begin{array}{l}0.048 \\
{[0.674]}\end{array}$ & & $\begin{array}{l}0.28 \\
{[0.017]^{* *}}\end{array}$ \\
\hline Informal payments & & $\begin{array}{l}0.337 \\
{[0.478]}\end{array}$ & & $\begin{array}{l}0.686 \\
{[0.192]}\end{array}$ \\
\hline \multicolumn{5}{|l|}{ Ownership and Control } \\
\hline Private Ownership & $\begin{array}{l}0.149 \\
{[0.082]^{*}}\end{array}$ & $\begin{array}{l}0.171 \\
{[0.062]^{*}}\end{array}$ & $\begin{array}{l}0.175 \\
{[0.038]^{* *}}\end{array}$ & $\begin{array}{l}0.188 \\
{[0.039]^{* *}}\end{array}$ \\
\hline Foreign Ownership & $\begin{array}{l}0.659 \\
{[0.231]}\end{array}$ & $\begin{array}{l}0.495 \\
{[0.394]}\end{array}$ & $\begin{array}{l}0.806 \\
{[0.186]}\end{array}$ & $\begin{array}{l}0.733 \\
{[0.256]}\end{array}$ \\
\hline Foreign Ownership Square & $\begin{array}{l}-0.852 \\
{[0.155]}\end{array}$ & $\begin{array}{l}-0.607 \\
{[0.337]}\end{array}$ & $\begin{array}{l}-0.781 \\
{[0.231]}\end{array}$ & $\begin{array}{l}-0.665 \\
{[0.336]}\end{array}$ \\
\hline State-Appointed CEO & $\begin{array}{l}-0.067 \\
{[0.542]}\end{array}$ & $\begin{array}{l}-0.051 \\
{[0.664]}\end{array}$ & $\begin{array}{l}0.067 \\
{[0.531]}\end{array}$ & $\begin{array}{l}0.106 \\
{[0.362]}\end{array}$ \\
\hline $\begin{array}{l}\text { State-Approved CEO } \\
\text { Nomination by firm }\end{array}$ & $\begin{array}{l}-0.288 \\
{[0.004]^{* * *}}\end{array}$ & $\begin{array}{l}-0.299 \\
{[0.005]^{* * *}}\end{array}$ & $\begin{array}{l}-0.052 \\
{[0.596]}\end{array}$ & $\begin{array}{l}-0.087 \\
{[0.409]}\end{array}$ \\
\hline Other Control Variables & & & & \\
\hline Average ROS & $\begin{array}{l}0.519 \\
{[0.000]^{* * *}}\end{array}$ & $\begin{array}{l}0.565 \\
{[0.000]^{* * *}}\end{array}$ & $\begin{array}{l}0.306 \\
{[0.003]^{* * *}}\end{array}$ & $\begin{array}{l}0.39 \\
{[0.000]^{* * *}}\end{array}$ \\
\hline Competition & $\begin{array}{l}-0.104 \\
{[0.000]^{* * *}}\end{array}$ & $\begin{array}{l}-0.098 \\
{[0.000]^{* * *}}\end{array}$ & $\begin{array}{l}-0.054 \\
{[0.036]^{* *}}\end{array}$ & $\begin{array}{l}-0.033 \\
{[0.239]}\end{array}$ \\
\hline Access to Finance & $\begin{array}{l}0.361 \\
{[0.000]^{* * *}}\end{array}$ & $\begin{array}{l}0.357 \\
{[0.000]^{* * *}}\end{array}$ & $\begin{array}{l}0.3 \\
{[0.000]^{* * *}}\end{array}$ & $\begin{array}{l}0.345 \\
{[0.000]^{* * *}}\end{array}$ \\
\hline Firm Size & $\begin{array}{l}0.185 \\
{[0.000]^{* * *}}\end{array}$ & $\begin{array}{l}0.184 \\
{[0.000]^{* * *}}\end{array}$ & $\begin{array}{l}0.179 \\
{[0.000]^{* * *}}\end{array}$ & $\begin{array}{l}0.183 \\
{[0.000]^{* * *}}\end{array}$ \\
\hline Firm Age & $\begin{array}{l}-0.004 \\
{[0.105]}\end{array}$ & $\begin{array}{l}-0.006 \\
{[0.054]^{*}}\end{array}$ & $\begin{array}{l}-0.01 \\
{[0.000]^{* * *}}\end{array}$ & $\begin{array}{l}-0.01 \\
{[0.001]^{* * *}}\end{array}$ \\
\hline City Dummy & yes & yes & yes & yes \\
\hline Industry Dummy & yes & yes & yes & yes \\
\hline Year Dummy & yes & yes & yes & yes \\
\hline Observations & 1900 & 1698 & 1896 & 1694 \\
\hline
\end{tabular}

Note: Product Innovation is a dummy variable which takes on the value one if the firm has introduced new products or entered new business line since 1999, and zero otherwise. Process Innovation is a dummy variable which takes on the value one if the firm has introduced new process improvements, new management techniques or new quality control in production process since 1999, and zero otherwise. The regressions are run with probit, which is based on standard maximum likelihood estimation with heteroskedasticity-robust standard errors clustering within firms. ***, **, * indicate significance at the $1 \%, 5 \%$ and $10 \%$ levels, respectively. P-values based on robust standard errors are in parentheses.***, **, * indicate significance at $1 \%, 5 \%$, and $10 \%$, respectively. P-values based on robust standard errors are in parentheses 
Table 8: Probit Regressions on R\&D Decisions in Large and Small Firms

\begin{tabular}{|c|c|c|c|c|}
\hline & \multicolumn{2}{|c|}{ Large Firms } & \multicolumn{2}{|c|}{ Small Firms } \\
\hline Specification & $(1)$ & $(2)$ & (3) & $(4)$ \\
\hline Contract Enforcement & & & & \\
\hline Contract & $\begin{array}{l}0.479 \\
{[0.012]^{* *}}\end{array}$ & $\begin{array}{l}0.446 \\
{[0.019]^{* *}}\end{array}$ & $\begin{array}{l}0.528 \\
{[0.008]^{* * *}}\end{array}$ & $\begin{array}{l}0.496 \\
{[0.014]^{* *}}\end{array}$ \\
\hline Contract Upheld & $\begin{array}{l}-0.138 \\
{[0.315]}\end{array}$ & $\begin{array}{l}-0.122 \\
{[0.380]}\end{array}$ & $\begin{array}{l}0.283 \\
{[0.070]^{*}}\end{array}$ & $\begin{array}{l}0.259 \\
{[0.094]^{*}}\end{array}$ \\
\hline Government Expropriation & & & & \\
\hline Helping Hand & $\begin{array}{l}0.111 \\
{[0.484]}\end{array}$ & $\begin{array}{l}0.134 \\
{[0.416]}\end{array}$ & $\begin{array}{l}0.46 \\
{[0.022]^{* *}}\end{array}$ & $\begin{array}{l}0.484 \\
{[0.014]^{* *}}\end{array}$ \\
\hline Efficient Service & $\begin{array}{l}0.353 \\
{[0.024]^{* *}}\end{array}$ & $\begin{array}{l}0.319 \\
{[0.049] * *}\end{array}$ & $\begin{array}{l}-0.115 \\
{[0.551]}\end{array}$ & $\begin{array}{l}-0.145 \\
{[0.446]}\end{array}$ \\
\hline Informal payments & $\begin{array}{l}0.616 \\
{[0.340]}\end{array}$ & $\begin{array}{l}0.694 \\
{[0.299]}\end{array}$ & $\begin{array}{l}-1.435 \\
{[0.076]^{*}}\end{array}$ & $\begin{array}{l}-1.388 \\
{[0.111]}\end{array}$ \\
\hline Ownership and Control & & & & \\
\hline Private Ownership & & $\begin{array}{l}0.149 \\
{[0.248]}\end{array}$ & & $\begin{array}{l}0.116 \\
{[0.465]}\end{array}$ \\
\hline Foreign Ownership & & $\begin{array}{l}1.898 \\
{[0.010]^{* * *}}\end{array}$ & & $\begin{array}{l}1.61 \\
{[0.104]}\end{array}$ \\
\hline Foreign Ownership Square & & $\begin{array}{l}-2.219 \\
{[0.008]^{* * *}}\end{array}$ & & $\begin{array}{l}-0.976 \\
{[0.358]}\end{array}$ \\
\hline State-Appointed CEO & & $\begin{array}{l}-0.283 \\
{[0.061]^{*}}\end{array}$ & & $\begin{array}{l}-0.188 \\
{[0.469]}\end{array}$ \\
\hline State-Approved CEO & & -0.302 & & 0.209 \\
\hline $\begin{array}{l}\text { Nomination by firm } \\
\text { Other Control Variables }\end{array}$ & & {$[0.042]^{* *}$} & & {$[0.264]$} \\
\hline Lagged ROS & $\begin{array}{l}0.214 \\
{[0.048]^{* *}}\end{array}$ & $\begin{array}{l}0.199 \\
{[0.069]^{*}}\end{array}$ & $\begin{array}{l}0.123 \\
{[0.167]}\end{array}$ & $\begin{array}{l}0.039 \\
{[0.646]}\end{array}$ \\
\hline Competition & $\begin{array}{l}-0.167 \\
{[0.000]^{* * *}}\end{array}$ & $\begin{array}{l}-0.16 \\
{[0.000]^{* * *}}\end{array}$ & $\begin{array}{l}-0.117 \\
{[0.004]^{* * *}}\end{array}$ & $\begin{array}{l}-0.13 \\
{[0.001]^{* * *}}\end{array}$ \\
\hline Access to Finance & $\begin{array}{l}0.328 \\
{[0.001]^{* * *}}\end{array}$ & $\begin{array}{l}0.272 \\
{[0.006]^{* * *}}\end{array}$ & $\begin{array}{l}0.271 \\
{[0.055]^{*}}\end{array}$ & $\begin{array}{l}0.336 \\
{[0.018]^{* *}}\end{array}$ \\
\hline Firm Size & $\begin{array}{l}0.197 \\
{[0.000]^{* * *}}\end{array}$ & $\begin{array}{l}0.22 \\
{[0.000]^{* * *}}\end{array}$ & $\begin{array}{l}0.294 \\
{[0.001]^{* * *}}\end{array}$ & $\begin{array}{l}0.363 \\
{[0.000]^{* * *}}\end{array}$ \\
\hline Firm Age & $\begin{array}{l}-0.007 \\
{[0.017]^{* *}}\end{array}$ & $\begin{array}{l}-0.002 \\
{[0.474]}\end{array}$ & $\begin{array}{l}-0.043 \\
{[0.000]^{* * *}}\end{array}$ & $\begin{array}{l}-0.037 \\
{[0.000]^{* * *}}\end{array}$ \\
\hline City Dummy & yes & yes & yes & yes \\
\hline Industry Dummy & yes & yes & yes & yes \\
\hline Year Dummy & yes & yes & yes & yes \\
\hline Constant & $\begin{array}{l}-2.87 \\
{[0.000]^{* * *}}\end{array}$ & $\begin{array}{l}-3.103 \\
{[0.000]^{* * *}}\end{array}$ & $\begin{array}{l}-2.371 \\
{[0.000]^{* * *}}\end{array}$ & $\begin{array}{l}-2.872 \\
{[0.000]^{* * *}}\end{array}$ \\
\hline Observations & 1648 & 1635 & 1657 & 1645 \\
\hline
\end{tabular}

Note: Large firms are the firms with firm size above sample median. Small firms are the firms with firm size below sample median. The regressions are run with probit, which is based on standard maximum likelihood estimation with heteroskedasticityrobust standard errors clustering within firms. ***, **,* indicate significance at the $1 \%, 5 \%$ and $10 \%$ levels, respectively. Pvalues based on robust standard errors are in parentheses. 